\title{
Effects of filter-feeding by the ribbed mussel Geukensia demissa on the water-column microbiota of a Spartina alterniflora saltmarsh
}

\author{
P. F. Kemp ${ }^{1}$, S. Y. Newell ${ }^{2}$, C. Krambeck ${ }^{3}$ \\ ${ }^{1}$ Oceanographic Sciences Division, Brookhaven National Laboratory, Upton, New York 11973, USA \\ ${ }^{2}$ University of Georgia Marine Institute Sapelo Island, Georgia 31327, USA \\ ${ }^{3}$ Max Planck Institute for Limnology, D-2320 Plön, Federal Republic of Germany
}

\begin{abstract}
We measured the effects of filtration by the Atlantic ribbed mussel Geukensia demissa (Dillwyn, 1817) on microbial abundance in water exposed to the salt-marsh surface. Various groups of living and non-living particles (large and small autotrophs, large and small heterotrophs, cyanobacteria, bacteria, non-living clay-organic floc) were removed with greatly differing effectiveness, ranging from 25 to $95 \%$ of initial abundance per hour Phytoplankton would contribute an estimated $72 \%$ of living microbial carbon removed by field populations of mussels $147 \%$ of living microbial carbon contributed by small autotrophs). Although an equal biomass of small mussels was more effective at removing particles than large mussels, medium to large mussels would account for over $90 \%$ of mussel grazing in the field because of their greater abundance. Particle removal was not solely dependent on particle size, as large heterotrophs and bacteria were removed with low (25 to $56 \% \mathrm{~h}^{-1}$ ) efficiency, whereas intermediate-sized living particles and non-living clay-organic particles (ranging widely in size) were removed with high efficiency (up to $95 \% \mathrm{~h}^{-1}$ ). Differential removal of small heterotrophs (high efficiency) versus bacteria (low efficiency) may perturb the balance between bacterial production and microbial bacterivory in salt-marsh systems. The presence of $G$. demissa enhanced bacterial production rates slightly; this could not be solely attributed to nitrogen excretion by the mussels. Mussel filtration was sufficient to balance bacterial production during high tide excursions of water onto the marsh, and may account for the net importation of bacteria from tidal creeks to the intertidal marsh reported in other studies. Present data indicate that ingestion of microbial carbon is not sufficient to meet the carbon requirements of $G$. demissa on an annual basis.
\end{abstract}

\section{INTRODUCTION}

The feeding activity of suspension-feeding bivalve molluscs can have a profound influence on the abundance of water-column microbiota in shallow water (Wright et al. 1982), and may be an important mechanism for coupling pelagic and benthic processes (Dame et al. 1980). Cloern (1982) suggested that the abundance of phytoplankton within the southern portion of San Francisco Bay is controlled by the effects of grazing by benthic bivalves, which could filter a water volume equivalent to the entire water column each day. Officer et al. (1982) considered the criteria which could lead to such control in south San Francisco Bay (shallow water, limited hydrodynamic exchange, dense benthic filter-feeding community) and identified 2 other estuarine systems which were also likely to exhibit benthic control of water-column microbial abundance. Peterson \& Black (1987) concluded that benthic bivalves could potentially filter a large fraction of incoming tidal volume on sandflats of a subtropical embayment (Shark Bay, Australia). Sherr et al. (1986) found that in the Duplin River estuary (Sapelo Island, Georgia, USA) much of bacterioplankton production was not grazed within the water column, and suggested that benthic filter-feeders may account for the removal of a substantial portion of the remaining bacterial production.

The bivalve Geukensia demissa is abundant in Spartina alterniflora Loisel. (smooth cordgrass) salt marshes such as those adjacent to the Duplin River, and has been shown to influence nitrogen flux (Jordan \& Valiela 1982), S. alterniflora production (Bertness 1984), and sedimentation (Smith \& Hopkinson 1983). Jordan \& Valiela (1982) estimated that G. demissa populations in a $\mathrm{New}$ England $S$. alterniflora salt 
marsh could potentially filter all or nearly all of the water in the marsh in every tidal cycle. G. demissa filtration therefore may control the abundance and composition of living and non-living particles in the water column, and profoundly influence pathways of energy and organic matter utilization in this highly productive system.

The evident importance of bivalves in nutrient and energy flux has led to numerous studies of both their food resources and of the potential effects of filtration by field populations; however, the actual rather than potential impact of bivalve grazing is still not well understood in most environments. Studies have frequently emphasized the use of laboratory cultures of potential food items, and subsequent extrapolation to field situations (e.g. Birbeck \& McHenery 1982, Stuart et al. 1982, Seiderer et al. 1984, McHenery \& Birbeck 1985, Shumway et al. 1985, Amouroux 1986a, b, Muir et al. 1986, Newell \& Langdon 1986, Riisgård 1988). However, the use of monospecific cultures rather than natural assemblages may substantially bias estimates of the effects of filtration in the field (Doering \& Oviatt 1986). The use of flumes and other enclosures, or other means of repeatedly sampling specific water parcels containing natural particles (e.g. Jordan \& Valiela 1982, Wright et al. 1982, Dame et al. 1985, Chrzanowski et al. 1986, Lucas et al. 1987, Peterson \& Black 1987, Frechette et al. 1989) may be more appropriate when the goal is to evaluate the impact of filtration by field populations.

We have conducted a series of flume and enclosure experiments to examine the effect on bacterioplankton and other microbiota of tidal excursions onto a Spartina alterniflora salt marsh. The present report considers the influence of filtration by Genkensia demissa of varying size on abundances of suspended microbes (bacteria, cyanobacteria, other large and small autotrophs, other large and small heterotrophs), and on the relative abundance of clay-organic floc particles. Our experimental design was to enclose the water column above equal-biomass groups of mussels of 3 size categories, and, following enclosure, to monitor changes in bacterial production and abundance, changes in the abundance and size spectra of other microbes, and changes in the abundance of non-living clay-organic particles. Specific questions to be addressed were: (1) Is filtration by field populations of $G$. demissa selective for different water-column microbiota? (2) Is $G$. demissa filtration sufficient to account for the removal of a substantial fraction of bacterioplankton production? (3) Does $G$. demissa filtration alter bacterial productivity either directly (e.g. nutrient release) or indirectly (e.g. removal of bacterivores)? (4) Can one predict from these data the relative importance of filtration by various size classes of mussels in the field?

\section{METHODS}

Mussels Geukensia demissa were collected in August 1986 from a Spartina alterniflora salt marsh (short plant height) adjacent to Sapelo Island, Georgia, USA. One group each of 1 large (shell height $=40 \mathrm{~mm}$ ), 3 medium $(26 \mathrm{~mm})$ or 10 small mussels $(16 \mathrm{~mm})$ were re-embedded in field-collected sediment in $10 \mathrm{~cm}$ diameter fired-clay flowerpots, with approximately one-third of the shell length protruding. Numbers per group were selected to result in approximately equal total biomass (ca 0.8 to $1.0 \mathrm{~g}$ shell-free dry weight) of each group, based on a weight-height regression for Sapelo Island populations (Kuenzler 1961). Mussels were allowed to re-attach by byssal threads to the flowerpot walls for $2 \mathrm{wk}$ in a running seawater aquarium, then placed in the field. The pots were embedded in the salt-marsh sediment near a creek bank (South End Creek, $1 \mathrm{~km}$ from Doboy Sound) in an area with plants of intermediate height, with the pot rims and interior sediment surface level with the marsh surface. Mussels were allowed to acclimate for $7 \mathrm{~d}$ in the field before the experiment. In addition to pots containing large, medium and small mussels, 3 pots with sediment but without mussels were prepared in an otherwise identical manner and were embedded in the marsh to serve as controls, as described below.

The experiment was initiated in daylight near slack high water (ca $1 \mathrm{~h}$ after immersion of the mussels) by enclosing each pot within a $20 \mathrm{~cm}$ diameter PVC cylinder which was pressed into a pre-cut channel in the sediment surface, and which projected $5 \mathrm{~cm}$ above the water surface at peak high tide. Cordgrass shoots within $10 \mathrm{~cm}$ of the pots had been removed to facilitate placement of the PVC cylinders. Salinity was $32 \%$ and water temperature was $28^{\circ} \mathrm{C}$ at the site. Samples of water within the cylinders $(30 \mathrm{ml})$ were removed at ca $15 \mathrm{~min}$ intervals from a depth of $10 \mathrm{~cm}$ (total water depth was 25 to $30 \mathrm{~cm}$ ) for direct counts and size measurements of microbiota. Separate water samples were collected at $15 \mathrm{~min}$ intervals for bacterial production measurements. Sampling was terminated after $1 \mathrm{~h}$. During the course of the experiment, a brief but vigorous (ca $1 \mathrm{~cm}$ total precipitation) rain shower occurred between 10 and 30 min after initiation.

The experimental conditions were designed to simulate filtration of water by field populations of Geukensia demissa in Sapelo Island marshes at high tide. The tidal elevation at the experimental site resulted in a mean water depth of $28 \mathrm{~cm}$ during the experiment, near to the mean high-tide water depths at the center of abundance of $G$. demissa populations $(20 \mathrm{~cm}$; Kuenzler 1961). Biomass densities of mussels within the cylinder enclosures, which were effectively mandated by the biomass of a single large mussel, were higher than 
average densities in Sapelo Island marshes. Kuenzler (1961) reported that the mean biomass of $G$. demissa in marshes near Sapelo Island was $4.1 \mathrm{~g}$ shell-free dry wt $\mathrm{m}^{-2}$, compared to the experimental density of 0.8 to $1.0 \mathrm{~g}$ shell-free dry wt per cylinder or ca $30 \mathrm{~g}$ shell-free dry wt $\mathrm{m}^{-2}$. The intensity of grazing within the cylinders therefore probably exceeds typical grazing intensity of average field populations during a $1 \mathrm{~h}$ slack tide. However, filtration also occurs but was not measured during rising and falling tides (ca $3 \mathrm{~h}$ total duration of immersion), when it was not possible to completely isolate the water within the cylinders from surrounding water (water height differentials of more than ca $5 \mathrm{~cm}$ resulted in leakage). This both increases the duration of exposure of water to filtering mussels and potentially increases the intensity of filtration, since a shallower water column implies more rapid depletion of suspended particles at a given filtration rate. As a caveat, the enclosures reduced any potential hydrodynamic effects of wind and water motion which could influence (e.g. via particle resuspension) particle concentration, and consequently filtration rates.

Two of the 3 cylinders without mussels were used to control for the potential effects of ammonium-nitrogen excretion by mussels on bacterial production. Ammonium chloride was added to one cylinder at a rate designed to simulate the excretion of ammonium$\mathrm{N}$ by one large mussel (31 $\mu \mathrm{g} \mathrm{N} \mathrm{h}^{-1}$ ), based on a regression of ammonia excretion on body weight for a New England Geukensia demissa population (Jordan \& Valiela 1982). The second cylinder received ammonium chloride to simulate excretion by 10 small mussels (106 $\mu \mathrm{g} \mathrm{N} \mathrm{h}^{-1}$ ). Ammonium was added as $5 \mathrm{ml}$ of stock solution every $10 \mathrm{~min}$ beginning at $2 \mathrm{~min}$ after enclosure; to facilitate mixing, each cylinder was stirred gently with a glass pipette for $10 \mathrm{~s}$ after the addition, taking care not to visibly resuspend sediment. The final control cylinder (no mussels, no additions) and each of the mussel cylinders were also stirred every $10 \mathrm{~min}$. However, the vigorous pumping action of mussels visibly disturbed the water surface within mussel cylinders and, we believe, considerably exceeded the intensity of mixing by pipette.

Water samples of $10 \mathrm{ml}$ were stained with diamidinophenylindole (DAPI) and filtered onto $0.2 \mu \mathrm{m}$ black Nuclepore filters. Filters were examined with a Zeiss epifluorescence microscope at $200 \times$ for large auto- and heterotrophic cells and at $1250 \times$ for small cells. All cells were measured at $1250 \times$ using a calibrated ocular micrometer. Autotrophic cells were identified by red autofluorescence under blue excitation light. Heterotrophic protozoa lacked chlorophyll autofluorescence but were located by the blue fluorescence of DAPI-stained DNA under ultraviolet excitation. Cyanobacteria were identified by red-orange auto- fluorescence under green excitation. Samples for bac terial abundance measurements were stained with acridine orange and examined under blue excitation at $2000 \times$. Bacterial sizes were measured for 50 cells per treatment by photographing fields (Kodak Ektachrome) and measuring well-focused cells in projections of slides at $10000 \times$, calibrating with a photograph of a stage micrometer (see Lee \& Fuhrman 1987). Abundances are the means of 10 field counts for cyanobacteria and bacteria (in each of 3 replicate subsamples), 25 fields for small and large autotrophs, and 50 fields for small and large heterotrophic protozoa. The relative abundance of non-living organic particles, which fluoresced red when stained with acridine orange (i.e. clay-organic floc: Newell et al. 1988) was expressed as a 'floc index'. The original abundance, dimensions and organic mass of floc in the water column is unknown and the floc index is presented solely as a relative measure of abundance, defined as the number of grid squares in a $6 \times 6$ grid reticle at $2000 \times$ which contained floc particles $>5 \mu \mathrm{m}$ in one dimension.

Biovolumes of all microbiota except heterotrophic bacteria were estimated from cell dimensions using a computer digitizing program which calculates volumes using formulae for up to 21 comparable geometric solid shapes (program MICROBIO, developed for P.F.K. by R. Hopcroft, Univ. Guelph, Ontario, Canada). The total carbon cleared from the water column was estimated for each mussel group and living particle type assuming that bacteria contain $220 \mathrm{fg} \mathrm{C} \mu^{-3}$ (Bratbak \& Dundas 1984), cyanobacteria contain $294 \mathrm{fg} \mathrm{C} \mathrm{cell}^{-1}$ (Cuhel \& Waterbury 1984), heterotrophic cells contain $80 \mathrm{fg} \mathrm{C} \mu \mathrm{m}^{-3}$ (Sherr \& Sherr 1984), and using Strathmann's (1967) regression equations for the carbon contents of diatoms and other autotrophic cells.

The incorporation of tritiated thymidine into DNA was measured to evaluate bacterial reproductive activity, using a combination of the methods of Riemann (1984) and Moriarty \& Pollard (1981). At each sampling time, 4 replicate $10 \mathrm{ml}$ water samples per treatment were added to scintillation vials containing tritiated thymidine $\left(20 \mathrm{Ci} \mathrm{mmole}^{-1}\right.$; final concentration $20 \mathrm{nM}$ thymidine; New England Nuclear, NEN). One vial also contained formaldehyde (final concentration $2 \%$ ) to serve as a time-zero killed control. Incubations were for $15 \mathrm{~min}$ in sealed vials while vials were suspended under water at the study site, and were terminated by the addition of formalin and placement on ice. Killed samples were filtered onto $0.45 \mu \mathrm{m}$ Gelman GN6 membrane filters and washed on the filter column $5 \times$ with $3 \mathrm{ml}$ ice-cold $5 \%$ trichloroacetic acid (TCA) to remove small acid-soluble molecules. Filters were then placed in centrifuge tubes, heated to $100^{\circ} \mathrm{C}$ for $30 \mathrm{~min}$ in $4 \mathrm{ml}$ of $5 \%$ TCA to hydrolyze DNA, cooled, and centrifuged at $5000 \times g$ to precipitate protein. Samples of the super- 
natant containing hydrolyzed labeled DNA were counted in Aquasol-2 (NEN) scintillation fluid. Activity was expressed as femtomoles $\left(10^{-15}\right.$ moles) of thymidine incorporated per $10^{6}$ cells.

Least-squares linear regressions of abundance on time were compared for each particle type among the 6 treatments by analysis of variance (ANOVA), using the $T^{\prime}$ method and Gabriel's (1978) approximate comparison intervals for multiple unplanned comparisons (Sokal \& Rohlf 1981). If regression slopes were not significantly different among treatments, analysis of covariance (ANCOVA) was used to compare the $\mathrm{Y}$ intercepts, again by the use of Gabriel's approximate comparison intervals. Although an exponential decrease in abundance through time might be more realistic given complete mixing of water within the cylinders (thorough mixing was likely in the mussel cylinders, but possibly not in control cylinders mixed only by gentle stirring) and a constant filtration rate (Coughlan 1969), the temporal resolution of our data does not warrant using other than a simple linear relationship.

Statistical analysis of thymidine incorporation data (fmole thymidine per $10^{6}$ cells per min) consisted of a 2 way Model I analysis of variance for treatment effects and for time (both fixed effects). Since treatments were not replicated, interactions cannot be tested and must be assumed negligible; we have in any case no a priori basis for expecting significant interaction.

\section{RESULTS}

The dominant taxa within each of the operationallydefined particle types were as follows: large autotrophic cells were primarily diatoms; large hetero-
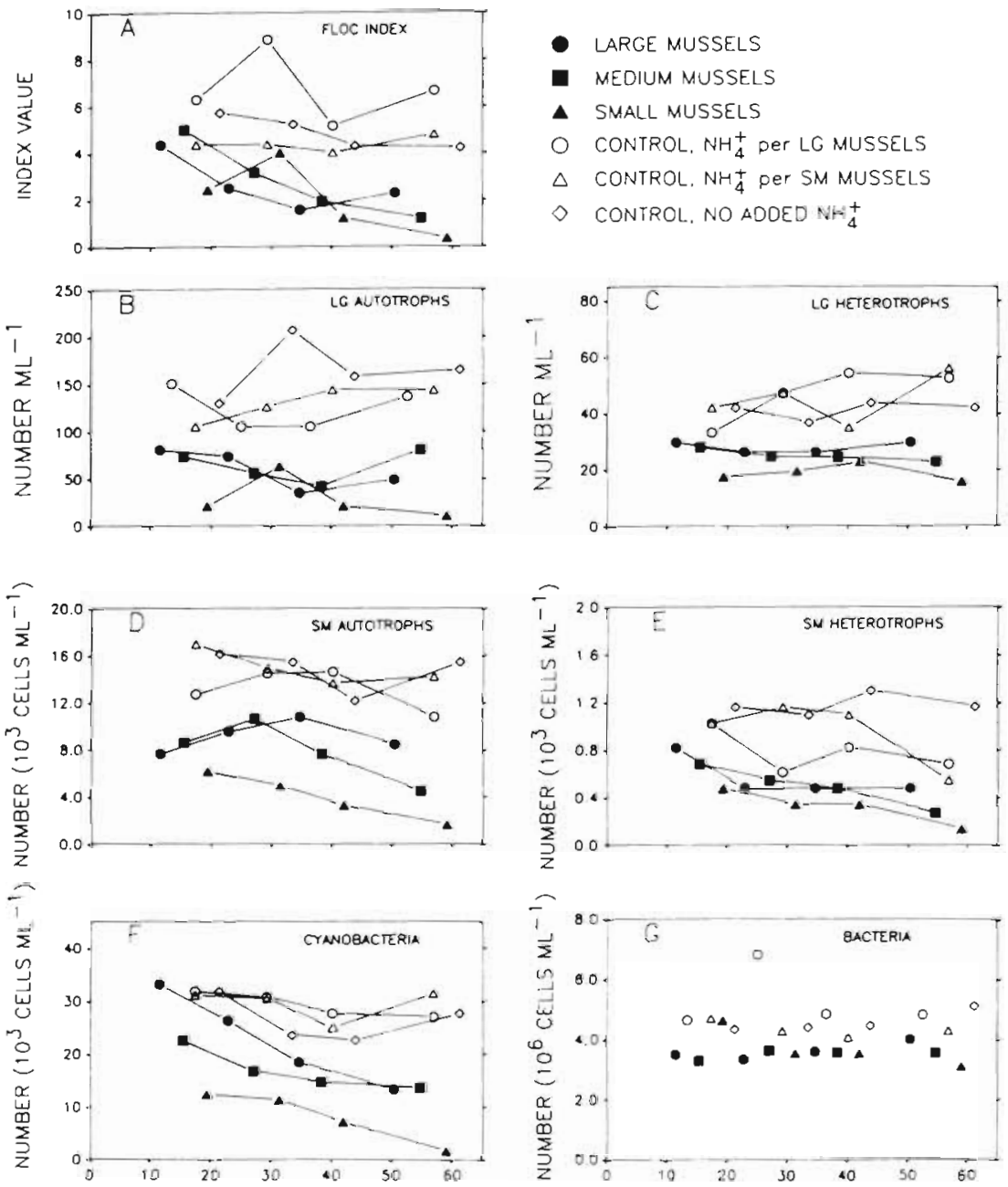

ELAPSED TIME (MIN)
Fig. 1 Abundances of (A) non-living clay-organic floc, (B) large autotrophs, (C) large heterotrophs, (D) small autotrophs, (E) small. heterotrophs, (F) $c y$ anobacterja and (G) bacteria through time in control cylinders (controls with ammonium added to correspond with excretion by large mussels, by small mussels, or with no ammonium added), and in cylinders containing 1 large, 3 medrum or 10 small mussels. Mussel biomass was approximately equal in each cylinder Floc index is a relative measure of abundance. Each abundance value represents the mean of 10,25 or 50 microscope fields (see text) converted to equivalent abundance per water volume (except floc index, unconverted data shown) 
trophic cells were primarily ciliates, but included some dinoflagellates; small autotrophic cells included some diatoms but were primarily chlorophyll-containing microflagellates; and small heterotrophs were primarily microflagellates lacking chlorophyll autofluorescence. Cyanobacteria were almost exclusively coccoidal in form.

Changes in the abundance of particles through time for each treatment are shown in Fig. 1A to G. Although the lack of replication precludes a rigorous statistical comparison of initial abundances between treatments, it is apparent that in most instances, particle abundance in the first samples taken was already lower in mussel treatments than in control treatments. However, continued decreases in abundance through the experiment are not generally apparent.

Slopes and Y-intercepts for regressions of abundance data on time are given in Table 1, together with the results of multiple comparisons among slopes (Gabriel's approximate comparison intervals) by ANOVA. Only 6 regression slopes were significant $(p<0.05)$; all were negative and 5 of the 6 were in treatments with

Table 1. Coefficients for regressions of particle abundances (cells $\mathrm{ml}^{-1}$, except floc) on time. ANOVA F-statistics (1, $2 \mathrm{df} ; \cdot \mathrm{p}$ $<0.05, \cdots p<0.01$ ) given for significance of regression slopes. Horizontal lines indicate slopes or adjusted means which were not significantly different at $p=0.05$ by ANOVA (slopes) or ANCOVA (means adjusted for common slope), using Gabriel's approximate comparison intervals based on the $T^{\prime}$ method (Sokal \& Rohlf 1981). Dashed lines connect non-adjacent values which are not significantly different

\begin{tabular}{|c|c|c|c|c|c|c|c|}
\hline & & \multicolumn{3}{|c|}{ Mussels } & \multicolumn{2}{|c|}{$\mathrm{NH}_{4}^{+}$controls } & \multirow{2}{*}{$\begin{array}{l}\text { Untreated } \\
\text { control }\end{array}$} \\
\hline & & Small & Medium & Large & Per lg. & Per sm. & \\
\hline \multirow{4}{*}{$\begin{array}{l}\text { Large } \\
\text { autotrophs }\end{array}$} & Slope & -0.532 & 0.227 & 0.666 & -0.222 & 01.151 & 0.369 \\
\hline & $\mathrm{F}$ & 0.51 & 0.11 & 1.00 & 0.05 & 5.40 & 0.09 \\
\hline & Y-intercept & 47.4 & 54.6 & 36.2 & 131.6 & 87.5 & 145.7 \\
\hline & Adjusted mean & 27.2 & 62.3 & 56.1 & 124.5 & 128.9 & 160.5 \\
\hline Large & Slope & --0.057 & -0.012 & 0.009 & 0.381 & 0.253 & 0.034 \\
\hline \multirow[t]{3}{*}{ heterotrophs } & $\mathrm{F}$ & 1.64 & 10.14 & 0.01 & 1.60 & 0.63 & 0.15 \\
\hline & Y-intercept & 19.7 & 29.1 & 27.8 & 34.8 & 35.6 & 40.3 \\
\hline & Adjusted mean & $\underline{17.5}$ & 25.0 & 28.1 & 46.9 & 44.7 & 41.7 \\
\hline Small & Slope & -113.2 & -112.3 & 13.5 & -41.8 & -35.7 & -70.6 \\
\hline \multirow[t]{3}{*}{ autotrophs } & $\mathrm{F}$ & $263.2^{\cdots}$ & 4.61 & 0.08 & 0.41 & 2.69 & 0.65 \\
\hline & Y-intercept & 8206 & 11486 & 8640 & 14422 & 15860 & 17033 \\
\hline & Adjusted mean & 3905 & 7674 & 9044 & 13086 & 14594 & 14206 \\
\hline Small & Slope & -7.77 & -10.2 & -9.64 & -1.13 & -13.0 & 1.13 \\
\hline \multirow[t]{3}{*}{ heterotrophs } & $\mathrm{F}$ & 7.14 & $143.6^{*}$ & 3.98 & 0.04 & 3.67 & 0.10 \\
\hline & $\mathrm{Y}$-intercept & 637.7 & 841.6 & 819.3 & 755.4 & 1409 & 1136 \\
\hline & Adjusted mean & 342.6 & 496.8 & 531.0 & 719.4 & 942.1 & 1181 \\
\hline \multirow[t]{4}{*}{ Cyanobacteria } & Slope & -2801 & --2151 & -5185 & -1329 & -168.6 & -1327 \\
\hline & $F$ & & 901 & 791 & 106 & 002 & $\overline{083}$ \\
\hline & $\mathrm{Y}$-intercept & 187827 & 242665 & 383784 & 336328 & 301671 & 312712 \\
\hline & Adjusted mean & 81397 & 169648 & 228768 & 293885 & 295599 & 259613 \\
\hline \multirow[t]{4}{*}{ Bacteria } & Slope & -34923 & 5557 & 14673 & 5274 & -9770 & 19165 \\
\hline & $F$ & 8.13 & 1.24 & 5.17 & 7.55 & 1.27 & 9.30 \\
\hline & Y-intercept & 5054846 & 3352364 & 3199562 & 4622377 & 4719242 & 3842966 \\
\hline & Adjusted mean & 3725500 & 3541000 & 3638250 & 4790750 & 4367500 & 4610000 \\
\hline \multirow[t]{4}{*}{ Floc index } & Slope & -0.029 & -0.029 & -0.015 & -0.003 & 0.002 & -0.009 \\
\hline & $\mathrm{F}$ & 4.21 & $54.31^{\circ}$ & 1.98 & 0.08 & 0.51 & 11.41 \\
\hline & Y-intercept & 2.43 & 2.60 & 2.04 & 2.69 & 2.01 & 2.56 \\
\hline & Adjusted mean & 1.32 & 1.63 & 1.61 & 2.58 & 2.10 & 2.21 \\
\hline
\end{tabular}


mussels. Regression slopes were not significantly different among all treatments for most particle types: the exceptions were for cyanobacteria, where smalland large-mussel treatments differed from the untreated control; and for bacteria, where the small-mussel treatment differed from all other treatments except one control cylinder. Analysis of covariance was conducted for all particle types to test the hypothesis that the mean abundance through time differed among mussel size groups (i.e. the means adjusted for a single, common regression slope were compared); however, since regression slopes were not entirely homogeneous among treatments for cyanobacteria and bacteria, the ANCOVA results may be somewhat suspect for these 2 particle types. ANCOVA indicated that the adjusted mean abundances (or equivalently, the Y-intercepts given a common regression slope) were significantly different $(p<0.05)$ between treatments with mussels

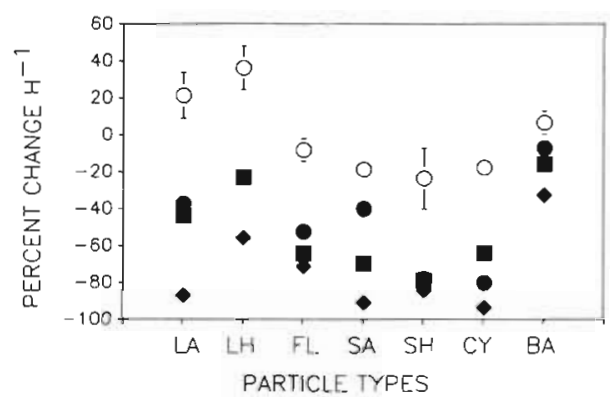

Fig. 2. Percent change in abundance of particles in control cylinders and in cylinders containing groups of 1 large, 3 medium or 10 small mussels. (o) Control cylinders, mean \pm 1 . $\mathrm{SE}, \mathrm{n}=3$. Other symbols as for Fig. 1. LA, LH, FL, SA, SH, CY and $\mathrm{BA}$ : large autotrophs, large heterotrophs, floc particles, small autotrophs, small heterotrophs, cyanobacteria and bacteria, respectively. Percent change calculated from mean predicted initial abundance in control cylinders minus predicted abundances after $60 \mathrm{~min}$

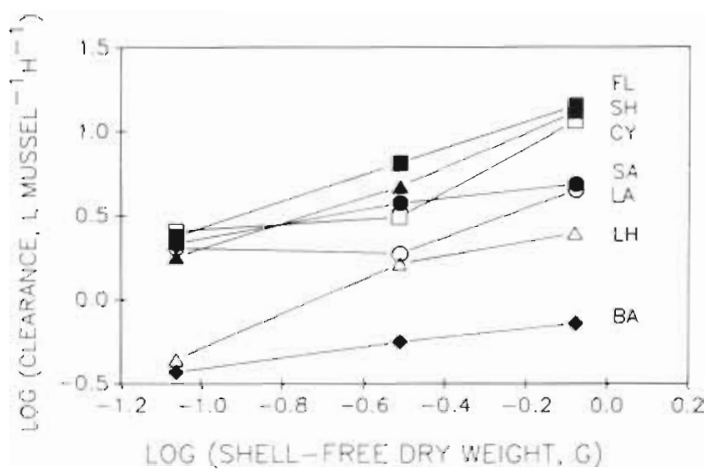

Fig. 3. Geukensia demissa. Clearance rate per individual mussel as a function of mussel size. Abbreviations as in Fig. 2. Filled symbols denote particles for which regression of clearance on mussel size was significant $(p<0.05$, ANOVA. Fstatistic for slope) and those without mussels for all particle types (Table 1). For all particles except bacteria and floc, the means were significantly lower for small mussels than for all other treatments. Means for medium-mussel and large-mussel treatments were not significantly different for all particle types except cyanobacteria. For most particle types, means were not significantly different among the 3 control treatments, with the notable exception of small heterotrophs for which all 3 control treatments were significantly different from each other and were larger than all mussel treatments, and floc particles for which the low-ammonium treatment (ammonium per large mussels) mean was larger than in all other cylinders.

At the end of the experiment when reduced particle abundance in mussel treatments allowed us to easily see the sediment surface, we observed that one of the 3 medium-sized mussels was completely closed and evidently not filtering. In the preceeding analysis, it is possible that ANCOVA comparisons of adjusted mean abundances would be somewhat affected, since presumably the final abundances of at least some particles would be lower in the presence of 3 actively filtering mussels

The linear regressions of particle abundance against time were used to estimate the initial abundance of particles in controls at time zero, representing our best estimate of the initial particle abundances in all cylinders. Percent change in abundance over $1 \mathrm{~h}$ was then calculated from these extrapolated initial abundances and the predicted abundance (from regressions) in mussel or control cylinders after $1 \mathrm{~h}$ for each particle type (Fig. 2). This calculation implicitly assumes that initial abundances varied randomly among all cylinders, such that variation in the initial abundance among cylinders will yield only random errors in our estimates of percent change. This is especially important in the case of consistently lower abundance in mussel cylinders than in control cylinders, which if merely a random event would be falsely interpreted as removal due to mussel feeding prior to the collection of the first sample. The assumption is supported by the low probability $(1 / 64)$ that random variations in the abundance of a given particle in the water column resulted in all 3 mussel cylinders having lower initial abundances than all 3 control cylinders. While the cumulative probability of any one of the 7 particle types showing this misleading pattern is $\gamma / 6 a^{2}$, the probability of at least 4 particle types showing this pattern (e.g. large autotrophs, large heterotrophs, small autotrophs and small heterotrophs: Fig. 1) is exceedingly low. By extension, we assume that variations in initial abundances of all other particles were also random.

The mean percent change in abundance in control cylinders was either positive (large heterotrophs and 
large autotrophs; positive but near zero for bacteria) or substantially less negative (all other particles) than in mussel cylinders (Fig. 2). Very similar patterns of particle removal for different particle types occurred for all 3 mussel size groups, with maximum removal of intermediate-sized living particles and non-living clayorganic particles, and lowest removal of large living particles and bacteria. Percent removal generally increased with decreasing mussel size; for some particle types, an equal biomass of small mussels removed more than twice as many particles than large mussels (Fig. 2; also weight-specific clearance rates in Table 2).

These predicted initial and final abundances of particles were also used to estimate the volume of water cleared of each particle type per hour by individual mussels of each size group (Fig. 3). Calculated clearance rates were based on the assumption that abundance decreased exponentially through time in a constant enclosed water volume with constant clearance rate, in order to yield rates comparable to published values (e.g. Jordan \& Valiela 1982, Wright et al. 1982); however, the temporal resolution of our own data is not sufficient to provide a reasonable test of this assumption. These rates should be regarded as the constant clearance rate required to yield decreases in abundance equivalent to those observed in the present study. Clearance rates have not been adjusted to compensate for changes in particle abundance in control cylinders, and therefore may somewhat underestimate (large autotrophs, heterotrophs and bacteria) or overestimate (other particles) true clearance rates. The estimated clearance rates $\left(1 \mathrm{~h}^{-1}\right.$ mussel $\left.{ }^{-1}\right)$ were analyzed by linear regression of the mean shell-free dry weight of mussels within a given group. Data were transformed $(\log X, \log Y)$ to fit an allometric relationship $\left(\mathrm{Y}=\mathrm{bX} \mathrm{X}^{\mathrm{a}}\right)$, which yielded much higher F-statistics than simple linear regression of untransformed data. Regression slopes were compared among particle types as for abundance data. Regression slopes were significant for floc particles ( $p<0.01$ ), small heterotrophs ( $p$ $<0.05$ ) and bacteria $(p<0.05)$, but not for small autotrophs $(\mathrm{p}<0.10)$, cyanobacteria $(\mathrm{p}>0.10)$ or large

Table 2. Estimates of living microbial carbon removed by Geukensia demissa filtration. Mussel biomass from Kuenzler (1961). Particle abundance and clearance rates from present data. Carbon removal (= carbon blomass of particles $\times$ weight-specific clearance rate $\times$ mussel biomass) multiplied by factor of 4 to extrapolate from biomass of these size classes to total mussel biomass in the field. $\mu=$ specific growth rate $\left(\mathrm{d}^{-1}\right)$, required to sustain microbial population against mussel grazing

\begin{tabular}{|c|c|c|c|c|c|}
\hline Particle type & $\begin{array}{c}\text { Particle } \\
\text { abundance } \\
\left(\mathrm{ng} \subset \mathrm{ml}^{-1}\right)\end{array}$ & $\begin{array}{c}\text { Clearance rate } \\
\left(\mathrm{ml} \mathrm{h}^{-1} \mathrm{mg}^{-1}\right. \\
\text { dry } \mathrm{wt})\end{array}$ & $\begin{array}{c}\text { Mussel } \\
\text { abundance } \\
\left(\mathrm{mg} \mathrm{m}^{-2}\right)\end{array}$ & 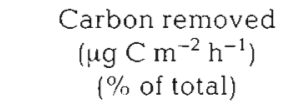 & $\mu$ \\
\hline \multicolumn{6}{|l|}{ Large mussels } \\
\hline Large autotrophs & 46.2 & 5.39 & 670 & $667.37 \quad(29)$ & 0.30 \\
\hline Large heterotrophs & 14.8 & 3.00 & & $119.22(5)$ & 0.17 \\
\hline Small autotrophs & 6.0 & 5.85 & & $939.16(40)$ & 0.32 \\
\hline Small heterotrophs & 1.6 & 15.64 & & 67.00 & 0.87 \\
\hline Cyanobacteria & 8.8 & 13.89 & & $328.39(14)$ & 0.77 \\
\hline Bacteria & 89.1 & 0.87 & & sum $=2328.98$ & 0.05 \\
\hline \multicolumn{6}{|l|}{ Medium mussels } \\
\hline Large autotrophs & 46.2 & 6.18 & 388 & $443.49(21)$ & 0.20 \\
\hline Large heterotrophs & 14.8 & 5.35 & & $123.24(6)$ & 0.17 \\
\hline Small autotrophs & 6.0 & 12.32 & & $1122.97(53)$ & 0.40 \\
\hline Small heterotrophs & 1.6 & 15.42 & & $38.25(2)$ & 0.50 \\
\hline Cyanobacteria & 8.8 & 10.16 & & $139.10(7)$ & 0.33 \\
\hline Bacteria & 89.1 & 1.83 & & $253.02(12)$ & 0.06 \\
\hline & & & & sum $=2120.85$ & \\
\hline \multicolumn{6}{|l|}{ Small mussels } \\
\hline Large autotrophs & 46.2 & 23.60 & 22 & $95.99(33)$ & 0.04 \\
\hline Large heterotrophs & 14.8 & 5.12 & & $6.69(2)$ & 0.01 \\
\hline Small autotrophs & 6.0 & 25.12 & & $132.46(45)$ & 0.05 \\
\hline Small heterotrophs & 1.6 & 20.81 & & $2.92(1)$ & 0.04 \\
\hline Cyanobacteria & 8.8 & 29.65 & & $23.01 \quad(8)$ & 0.05 \\
\hline \multirow[t]{2}{*}{ Bacteria } & 89.1 & 4.30 & & $33.71(11)$ & 0.01 \\
\hline & & & & sum $=294.79$ & \\
\hline
\end{tabular}


Table 3. (A) Two-way analysis of variance without replication of thymidine incorporation (fmol $10^{6}$ cells $\mathrm{s}^{-1} \mathrm{~min}^{-1}$ ). Factors are treatments and sampling set (1st through 4th sample sets). Interactions assumed negligible. (B) Thymidine incorporation data from mussel and control cylinders are pooled into 2 treatments with 3 replicates each. Two-way analysis of variance: factors are presence/absence of mussels and sample set; interaction tested. LSD test used for pairwise comparisons among sample sets

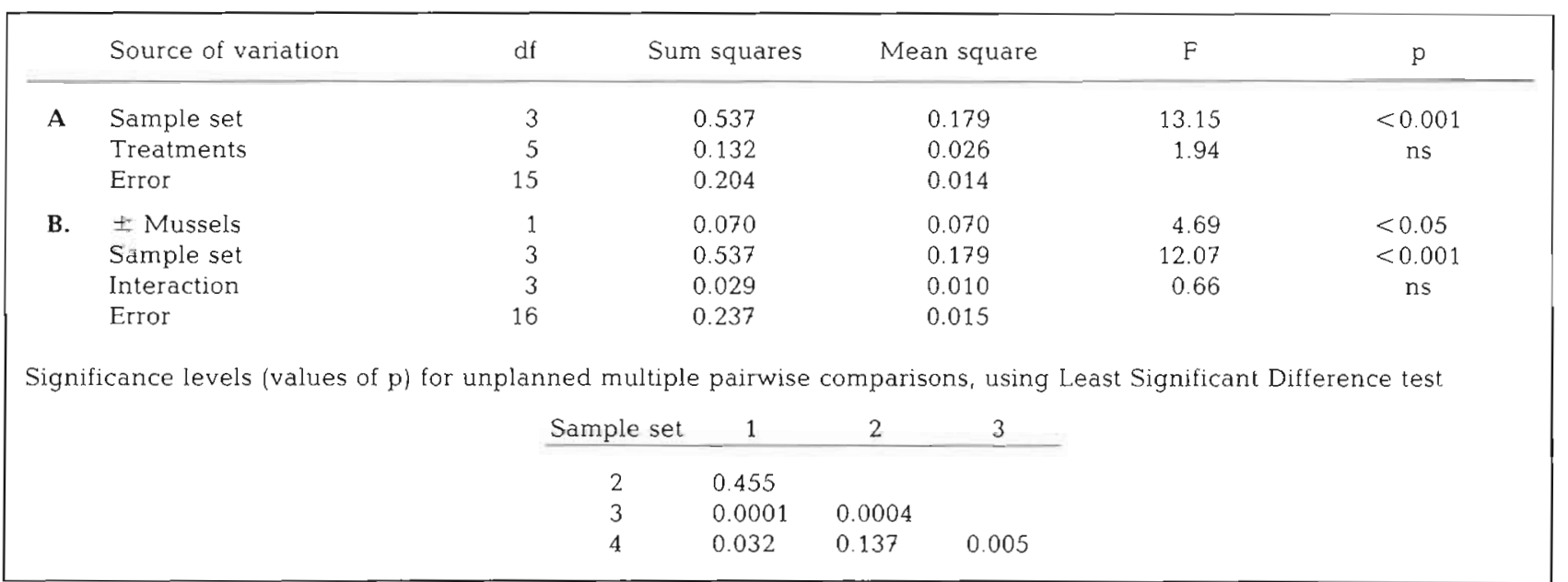

autotrophs and heterotrophs ( $p>0,10)$. ANCOVA comparisons among all regression slopes indicated no significant differences among particle types. The common slope for all particles was 0.565 .

The total carbon removed as large and small autotrophs, large and small heterotrophs, cyanobacteria and bacteria was evaluated from the calculated clearance rates and initial biomasses of microbiota in control cylinders. Carbon removal was expressed on an areal basis using Kuenzler's (1961) data for mussel abundance and biomass in Sapelo Island marshes. Mussel biomasses in Table 2 are Kuenzler's reported values for size groups which contain the 3 sizes used in the present experiment. We wished to extrapolate our data for 3 mussel size groups to field populations. Since the summed biomass of mussels in the size classes we used

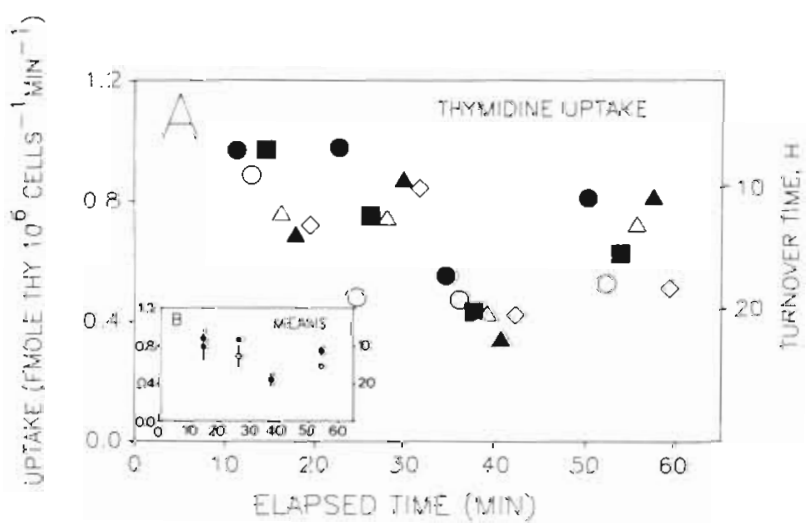

Fig. 4. (A) Incorporation of thymidine into DNA through time per million bacterial cells. Equivalent turnover time on alternate ordinate axis. Symbols as in Fig. 1. (B) Mean incorporation ( $=1 S E, n=3$ ) in all control cylinders (open) and in all mussel cylinders (filled) is roughly one-fourth of total biomass in field populations (Kuenzler 1961), we have (as a first approximation) multiplied the estimated removal due solely to our 3 size groups by a factor of 4 . The specific growth rate $\mu\left(\mathrm{d}^{-1}\right)$ required to balance mussel grazing was calculated for each type of living food particle (Table 2), as a convenient expression of the potential impact of mussel grazing on water column microbial populations.

Two-way analysis of variance of thymidine incorporation (fmol $10^{6}$ cells $^{-1} \mathrm{~min}^{-1}$ ), indicated no significant differences among treatments (Table 3A). However, there was a very highly significant difference among sampling sets $(p<0.001)$. Although conservative a posteriori tests of all possible pairwise comparisons showed no significant difference between any 2 sets, thymidine incorporation was substantially lower in both mussel and control treatments in the third set of samples than in the remaining 3 sets (Fig. 4A, B). We also noted that incorporation in mussel cylinders tended to be higher than in control cylinders (Fig. 4B). To further examine these differences in incorporation among sampling times and between mussel and control cylinders, we treated mussel and control cylinders as 2 treatments with 3 replicates each in a 2-way ANOVA followed by the Least Significant Difference test (Sokal \& Rohlf 1981) for unplanned comparisons among means (Table 3B). Thymidine incorporation in the third sample set was indeed significantly lower than in the remaining sets (all $p<0.01$ ); in addition, incorporation in the fourth set was significantly lower than in the first set $(p<0.05)$. Incorporation in mussel cylinders was significantly higher (11 to $28 \%$ greater in first, second and fourth sample sets) than in control cylinders $(p=0.04)$. Treatment $\times$ time interaction was not significant. 
Bacterial turnover times fell generally in the range of 10 to $20 \mathrm{~h}$ (Fig, 4A, B), estimated from thymidine incorporation on the assumption that thymidine concentrations were sufficiently high to inhibit de novo synthesis (see Riemann et al. 1987) and avoid significant isotope dilution (Moriarty 1986), and using a conversion factor of $2 \times 10^{18}$ cells produced mole ${ }^{-1}$ thymidine incorporated into DNA (Moriarty 1986).

\section{DISCUSSION}

Adjusted means were significantly lower for all mussel cylinders than in control cylinders for all particles. In a minority of cases, a significant continuing decrease in particle abundance was observed during the course of the experiment (significant negative regression slopes); in the majority of instances either most particle removal occurred early in the experiment (perhaps before the first sample was taken), or our data set simply lacks the resolution necessary to measure such continuing decreases in particle abundance. Given that consistent differences in particle abundance between mussel and control cylinders are unlikely to have happened by random chance, we assume that the lower particle abundances in mussel cylinders are due to feeding activity. The apparent removal of particles prior to collection of the first samples, coupled with no evidence for continued removal of some particle types, was both unexpected and puzzling, particularly since it appears that other particle types continued to be removed. These results may reflect a substantial capacity of Geukensia demissa to select among particles and possibly to alter selective preference over a short time span.

Because mussel abundance in treatment cylinders was higher than normal field densities, the degree to which particles were removed is probably greater than the expected removal of microbial particles in the field over a $1 \mathrm{~h}$ period at slack tide. However, similar removal of particles may occur over an entire tidal immersion in the field, including the rising and falling tides. In flume studies in the field (see Chalmers et al. 1985 concerning flume characteristics) we have found decreases in abundance during a $3 \mathrm{~h}$ tidal excursion which were similar in magnitude to decreases observed in this $1 \mathrm{~h}$ experiment (e.g. $74 \%$ reduction of floc, $33 \%$ reduction of bacteria in the flume: Newell \& Krambeck unpubl.; ca $90 \%$ reduction of floc, $30 \%$ reduction of bacteria in cylinders: present study). These results are in agreement with other studies showing seston depletion (and consequently food limitation) in the benthic boundary layer resulting from bivalve filtration (Wildish \& Kristmanson 1984, Frechette \& Bourget 1985a, b, Peterson \& Black 1987, Frechette et al. 1989). In the shallow water column overlying Geukensia populations in southeastern marshes, these suspension-feeding bivalves may also be food-limited.

Particles of various types were removed from the natural assemblage of suspended living and dead organic matter with greatly varying effectiveness. Riisgård (1988) found that from 70 to $100 \%$ of particles from 2 to $4 \mu \mathrm{m}$ diameter were removed by Geukensia demissa during incubations of $1 \mathrm{~h}$ or less; removal was effectively constant at $100 \%$ for particles above $4 \mu \mathrm{m}$ in diameter. In the present study, this range (2 to $9 \mu \mathrm{m})$ would be represented primarily by larger cyanobacteria, small autotrophic and small heterotrophic cells (5 to $10 \mu \mathrm{m}$ diameter), and probably by a substantial fraction of floc particles. For particles within this size range and for typically smaller cyanobacterial cells (mean diameter $1.2 \mu \mathrm{m}$ ), we found removal efficiencies (fraction of particles retained in $1 \mathrm{~h}$; Fig. 3) of 70 to $90 \%$, comparable to the results of Riisgård who used primarily cultured algae rather than a natural assemblage. Riisgård (1988) and Wright et al. (1982) suggested that its characteristically closely-spaced gill structure enabled $G$. demissa to remove small particles more efficiently than other bivalve species. However, in the present study removal efficiency decreased for still larger particles, suggesting that factors such as particle motility (especially in the case of large heterotrophs) or other factors which determine particle 'quality' (e.g. surface chemistry; Shumway et al. 1985) sometimes may be of greater importance than particle size.

Although particle removal is not equivalent to utilization by mussels (particles may be rejected in pseudofeces; various particles may be assimilated with differing efficiencies), it does set limits on the accessibility of various potential food items to Geukensia demissa. Phytoplankton (small and large autotrophs) would contribute $72 \%$ (small autotrophs $47 \%$ ) and bacteria could contribute $10 \%$ of total carbon filtered as living particles by mussels, based on extrapolations of our data to field populations (Table 2); the estimated contributions of other microbes would be $6 \%$ for large heterotrophs, $2 \%$ for small heterotrophs, and $10.5 \%$ for cyanobacteria. These data indicate a somewhat less important role for bacteria than suggested by Wright et al. (1982), who estimated that bacteria provided about one-fourth as much carbon to $G$. demissa as phytoplankton. As a first approximation, by assuming equal assimilation efficiency for all living particles we can predict that phytoplankton, especially smaller autotrophs, are likely to be the primary microbial food resource of $G$. demissa, with a substantial but lesser contribution from cyanobacteria and bacteria. Small heterotrophs are removed with efficiencies similar to small autotrophs but are insufficiently numerous to be an important carbon source. Large heterotrophs are not 
efficiently removed by $G$. demissa and are also insufficiently numerous. It is possible that the removal and assimilation efficiencies for non-living clay-organic floc are sufficiently high to allow a substantial incorporation of non-living carbon; Kreeger et al. (1988) estimated that suspended cellulosic detritus could provide as much as $15 \%$ of the carbon requirements of Delaware populations of $G$. demissa during the summer. Our estimate of the relative importance of different particle types is partially dependent on their relative abundances, which may vary seasonally, and should be considered representative only for summer.

In evaluating the removal of various particle types and the possible contributions of various particles to mussel requirements, we point out again that we have not corrected for apparent removal or increasing abundance of particles within control cylinders. Although regression ANOVA/ANCOVA analyses showed little statistical support for changing abundances in control cylinders, our calculations of percent removal (Fig. 2) suggest that small changes in abundance, generally of \pm 0 to $20 \%$, may have occurred for some particles. Since it is likely that mussel cylinders were mixed much more vigorously than control cylinders, abiotic processes such as particle settling and resuspension may not have been comparable between mussel and control cylinders. Correcting for apparent changes in particle abundance within control cylinders would increase the estimated removal (and importance to mussels) of large autotrophs, large heterotrophs and bacteria, and decrease that of small autotrophs, small heterotrophs, cyanobacteria and floc.

Maximal clearance rates (l cleared of particles), which may be most representative of actual filtration rates (l pumped), were $18.4 \mathrm{l} \mathrm{g}^{-1}$ shell-free dry weight $\mathrm{h}^{-1}$ for large mussels clearing cyanobacteria, $16.0 \mathrm{lg}^{-1}$ shell-free dry weight $h^{-1}$ for medium mussels clearing small heterotrophs, and $30.4 \mathrm{l} \mathrm{g}^{-1}$ shell-free dry weight $\mathrm{h}^{-1}$ for small mussels clearing cyanobacteria. These maximal clearance rates are higher than reported weight-specific clearance rates for Geukensia demissa feeding on small cultured algae (Riisgård 1988: 6.35, 7.52 and $9.33 \mathrm{~g} \mathrm{~g}^{-1} \mathrm{~h}^{-1}$ for mussels equal in size to our large, medium and small mussels, respectively), natural suspended particles 5 to $15 \mu \mathrm{m}$ in diameter (Jordan \& Valiela 1982: $3.90,7.21$ and $15.731 \mathrm{~g} \mathrm{~g}^{-1} \mathrm{~h}^{-1}$ for mussels equivalent to large, medium and small mussels), or unspecified total phytoplankton measured as chlorophyll a (Wright et al. 1982: $1.1 \mathrm{lg}^{-1} \mathrm{~h}^{-1}$ for relatively large mussels). However, our clearance rates calculated from the removal of large and small autotrophs were 5.3 and $5.8 \mathrm{~g} \mathrm{~g}^{-1} \mathrm{~h}^{-1}$ for large mussels and 5.9 and $12.3 \mathrm{lg}^{1} \mathrm{~h}^{-1}$ for medium mussels, similar to rates determined by Riisgård (1988) using 3 to $9 u m$ cultured algae as food. Reported clearance rates are also strongly dependent on mussel size, with a common slope of 0.565 in the allometric relationship; this value is between values reported by Jordan \& Valiela (1982; 0.385 in summer, 0.404 in fall) and by Riisgård (1988, also references cited therein; 0.73 to 0.83 ). The large differences in reported clearance rates of bivalves in various studies (e.g. $30 \times$ difference between Riisgård [1988] and Mohlenberg \& Riisgård [1978] for Mytilus edulis) may result from the particle type from which clearance is estimated, and the size range of individuals used in experiments. It is also possible that particle concentration, which strongly influences feeding rates, may be sufficiently different between studies to result in large variations in reported clearance rates.

We can estimate the local impact of Geukensia demissa filtration on water column microbiota from weight-specific clearance rates and the known biomass of mussels in Sapelo Island marshes. Based on the average biomass of mussels in Sapelo Island marshes in various size categories as reported by Kuenzler (1961), our weight-specific clearance rates (Table 2) would indicate that ca $100 \mathrm{l} \mathrm{m}^{-2} \mathrm{~h}^{-1}$ would be filtered by an average $G$. demissa population in summer during periods of tidal immersion. In terms of water passing over the marsh, this filtration rate at maximum clearance efficiency would result in the removal of $78 \%$ of particles in a water column averaging $20 \mathrm{~cm}$ deep exposed to G. demissa for $3 \mathrm{~h} ; 20 \mathrm{~cm}$ water depth is the median high-tide water depth over a broad range of elevations at which G. demissa occurs (Kuenzler 1961). Because small mussels are a comparatively minor component of the mussel population (Kuenzler 1961), medium to large mussels can be expected to remove the largest fraction of microbial biomass from the water column (Table 2). For bacteria-sized particles removed with lower efficiencies, roughly $25 \%$ of particles would be removed under the same conditions, i.e. about $13 \%$ $\mathrm{h}^{-1}$ if particle abundance decreased exponentially through time. The actual removal may be somewhat higher, since these estimates are based on our clearance rates which did not take into account bacterial growth during the course of the $1 \mathrm{~h}$ experiment. The overall mean bacterial production within the cylinders was $11 \%$ of initial abundance per hour, suggesting that G. demissa grazing would balance or possibly exceed bacterial production during high tide excursions of tidal creek water onto the marsh surface. Our flume data for summer conditions do, in fact, indicate a decrease in bacterioplankton abundance during tidal excursions over beds of $G$. demissa (Newell \& Krambeck unpubl.), supporting the conclusion that grazing may exceed production.

Sherr et al. (1986) calculated that nanoplanktonic bacterivores consume less than $50 \%$ of bacterial production in the salt-marsh creek water column and sug- 
gested that benthic filter-feeders such as Geukensia demissa may account for a significant part of the net importation of bacteria to the marsh observed by others (Erkenbrecher \& Stevenson 1975, Rublee et al. 1983). Our data are consistent with this hypothesis, although a more elaborate estimation of the total impact of grazing on water column microbes in salt-marsh creeks would be inappropriate for the present, limited data set.

Mussel grazing on particles other than bacteria would be balanced by specific growth rates in the range of 0.35 to $1.41 \mathrm{~d}^{-1}$. These rates are sufficiently similar to reported growth rates of phytoplankton and heterotrophic protozoans to suggest that mussel grazing has a significant impact on microbial abundance in water exposed to the marsh surface. The overall effect on microbial populations in salt marsh creeks would presumably be dependent on the proportion of creek water which is exposed to the marsh surface and subject to filtration.

Mussels may also have an indirect influence on microbial processes in the water column, for example by nutrient enhancement of microbial production, by perturbing the relative abundances of planktonic consumers and their prey, or by altering the abundance of clay particles which may adsorb organic matter. With regard to potential effects of nutrient release on bacteria, mean cell-specific thymidine incorporation was slightly enhanced (11 to $28 \%$ ) in the presence of mussels. There was no evident pattern to suggest that nitrogen additions resulted in similarly enhanced cellspecific thymidine incorporation in control cylinders. Consequently, the enhancement of thymidine incorporation in the presence of mussels cannot be attributed to excretion of ammonium- $\mathrm{N}$ by mussels. Other excretory products, or nutrients released during feeding, may have stimulated bacterial activity in the presence of mussels. Alternatively, grazing on bacteria may stimulate cell-specific activity, as has been suggested for various benthic and planktonic grazers (e.g. Alongi 1985, Moriarty et al. 1985, Simon 1987).

It is interesting that the enhancement of cell-specific activity in the presence of mussels was quite small in comparison to the drop in activity which occurred in the third set of samples (Fig. 4A, B). We hypothesize that this decrease may have been a response to the sudden, though small (i.e. $3.3 \%$ ) dilution of tidal water by a brief, heavy rain shower between 10 and 30 min after the start of the experiment. Whatever the cause of the decrease in activity, cell-specific thymidine uptake had returned nearly to previous levels by the fourth sample set collected only 15 min later. This illustrates the potential rapidity of substantial changes in bacterial activity, on temporal scales much shorter than reported diel (e.g. Moriarty \& Pollard 1982, Turley \& Lochte 1986, Kemp 1988) or longer (e.g. Newell et al. 1988) cycles.
Small heterotrophic cells, principally nanoflagellates, which are now considered important consumers of bacterioplankton, were removed with much greater efficiency (ca $89 \%$ per h) than bacteria ( $<30 \%$ per h) by all mussel size groups. This differential removal would tend to perturb the balance between bacterial production and grazing by bacterivores by releasing bacteria from grazing pressure, and could significantly influence microbial trophodynamics in the upper portions of salt-marsh creeks. Among large heterotrophs, ciliated protozoa are frequently considered omnivorous or algivorous but can be potentially important bacterivores in coastal water such as the Duplin River (Sherr \& Sherr 1987). Large heterotrophs, however, were generally removed at efficiencies similar to the removal of bacteria. As a result, mussel grazing would not be expected to significantly alter the balance between ciliate grazing and bacterial production.

We can estimate the flux of carbon onto the salt marsh due to mussel filtration. These rough estimates should be considered to substantially overestimate the annual removal of microbial carbon and non-microbial particulate organic carbon (POC), since filtration rates are based on summer, warm-water conditions; our winter data for an intertidal flume indicate substantially lower filtration rates. Geukensia demissa would remove at most $7.52 \mathrm{~g} \mathrm{C} \mathrm{m}^{-2} \mathrm{yr}^{-1}$ in living microbial carbon from the water column (from Table 2, given immersion for an average of $18 \%$ of the time [Kuenzler 1961 J). Given a POC concentration of $3 \mu \mathrm{g} \mathrm{ml} \mathrm{ml}^{-1}$ in the water column (Chalmers et al. 1985), a maximum of $\mathrm{ca}$ $417 \mathrm{~g} \mathrm{POC} \mathrm{m}^{-2} \mathrm{yr}^{-1}$ would be removed by field populations of $G$. demissa if POC is removed with equal efficiency to the floc in the present experiment. This is on the order of the estimated retention of POC in intertidal flumes: Chalmers et al. (1985), for example, estimated a mean POC retention within a flume of $360 \mathrm{mg} \mathrm{C} \mathrm{m}^{-2}$ per tide, equivalent to $260 \mathrm{~g} \mathrm{C} \mathrm{m}^{-2} \mathrm{yr}^{-1}$ for semi-diurnal tides.

Kuenzler (1961) estimated the annual assimilation of field populations near Sapelo Island at $56 \mathrm{~kg}-\mathrm{cal} \mathrm{m} \mathrm{m}^{-2}$ $\mathrm{yr}^{-1}$, equivalent to ca $7 \mathrm{~g} \mathrm{C} \mathrm{m}^{-2} \mathrm{yr}^{-1}$ (using conversion factors in Kuenzler 1961). If the carbon assimilation efficiency for Geukensia demissa is ca $50 \%$ (Jordan \& Valiela 1982), these populations would be expected to ingest ca $14 \mathrm{~g} \mathrm{C} \mathrm{m}^{-2} \mathrm{yr}^{-1}$ from the water column. Our maximal estimate of $7.52 \mathrm{~g} \mathrm{C} \mathrm{m}^{-2} \mathrm{yr}^{-1}$ ingested suggests that microbial carbon supplies a substantial portion, but not all of the requirements of $G$. demissa. Assimilation of non-living POC may provide the remainder.

Filtration of living carbon by Geukensia demissa represents only a very small fraction of the total carbon produced in the salt-marsh system or exported from salt marshes to the nearshore region (Chrzanowski et al. 
1982), in strong contrast with the impact of filtration by salt marsh oyster reef communities where net importation of living carbon can greatly exceed the estimated export of total POC from the salt-marsh system (import $=1750 \mathrm{~g} \mathrm{C} \mathrm{m}^{-2} \mathrm{yr}^{-1}$ : Chrzanowski et al. 1986). Thus, while grazing on microbes probably provides a substantial fraction of the carbon requirements of $G$. demissa, strongly influences the abundance of microbes in water exposed to the marsh surface, and may be important to microbial trophodynamics within the salt-marsh creek water column, our data suggest it is relatively unimportant in terms of total flux of living carbon in the salt marsh system.

Acknowledgements. The authors thank L. Kemp and B. Newell for their able assistance in the field. Support for this research was provided to P. F. K by a University of Georgia Marine Institute Postdoctoral Associateship and to C. K. by the University of Georgia Marine Institute Visiting Scientist Program. This report was prepared during an appointment (P.F.K.) to the Alexander Hollaender Distinguished Postdoctoral Fellowship Program supported by the U.S. Department of Energy, Office of Health and Environmental Research, and administered by Oak Ridge Associated Universities. This is contribution No. 642 of the University of Georgia Marine Institute.

\section{LITERATURE CITED}

Alongi, D. M. (1985). Effect of physical disturbance on population dynamics and trophic interactions among microbes and meiofauna. J. mar. Res. 43: 351-364

Amouroux, J. M. (1986a). Comparative study of the carbon cycle in Venus verrucosa fed on bacteria and phytoplankton I. Consumption of bacteria (Lactobacillus sp.). Mar Biol. 90: 237-241

Amouroux, J. M. (1986b). Comparative study of the carbon cycle in Venus verrucosa fed on bacteria and phytoplankton II. Consumption of phytoplankton (Pavlova lutheri). Mar Biol. 92: 349-354

Bertness, M. D. (1984). Ribbed mussels and Spartina alterniflora production in a New England salt marsh. Ecology 65 : 1794-1807

Birbeck, T H., McHenery, J. G. (1982). Degradation of bacteria by Mytilus edulis. Mar Biol. 72: 7-15

Bratbak, G., Dundas, I. (1984). Bacterial dry matter content and biomass estimations. Appl. environ. Microbiol 48: 755-757

Chalmers, A. G., Wiegert, R. G., Wolf, P. L. (1985). Carbon balance in a salt marsh: interaction of diffusive export, tidal deposition and rainfall-caused erosion. Estuar. cstl Shelf Sci. 21: 757-771

Chrzanowski, I H., Spurrier, J. D., Dame, R. F., Zingmark, R. G. (1986). Processing of microbial biomass by an intertidal reef community. Mar Ecol. Prog. Ser 30: 181-189

Chrzanowski, T H., Stevenson, L. H., Spurrier, J. D. (1982). Transport of microbial biomass through the North Inlet ecosystem. Microb. Ecol. 8: 139-156

Cloern, J. E. (1982). Does the benthos control phytoplankton biomass in south San Francisco Bay? Mar. Ecol. Prog. Ser. 9: $191-202$

Coughlan, J. (1969). The estimation of filtering rate from the clearance of suspensions. Mar Biol. 2: 356-358
Cuhel, R. L., Waterbury, J B. (1984). Biochemical composition and short-term nutrient incorporation patterns in a unicellular marine cyanobacterium, Synechococcus (WH7803). Limnol. Oceanogr. 29: 370-373

Dame, R., Zingmark, R., Stevenson, L. H., Nelson, D. (1980). Filter feeder coupling between the estuarine water column and benthic subsystems. In: Kennedy, V. S. (ed.) Estuarine perspectives. Academic Press, New York, p. 521-527

Dame, R. F., Wolaver, T. G., Libes, S. M. (1985). The summer uptake and release of nitrogen by an intertidal oyster reef. Neth. J. Sea Res 19: 265-268

Doering, P. H., Oviatt, C. A. (1986). Application of filtration rate models to field populations of bivalves: an assessment using experimental mesocosms. Mar. Ecol. Prog. Ser. 31: 265-275

Erkenbrecher, C. W., Stevenson, L. H. (1975). The influence of tidal flux on microbial biomass in salt marsh creeks. Limnol. Oceanogr. 20: 618-625

Frechette, M. Bourget, E. (1985a). Energy flow between the pelagic and benthic zones: factors controlling particulate organic matter available to an intertidal mussel bed. Can. J. Fish. Aquat. Sci. 42: 1158-1165

Frechette, M., Bourget, E. (1985b). Food-limited growth of Mytilus edulis $\mathrm{L}$. in relation to the benthic boundary layer. Can. J. Fish. Aquat. Sci. 42: 1166-1170

Frechette, M., Butman, C. A., Geyer, W. R. (1989). The importance of boundary-layer flows in supplying phytoplankton to the benthic suspension feeder, Mytilus edulis L. Limnol. Oceanogr 34: 19-36

Gabriel, K R. (1978). A simple method of multiple comparison of means. J. Am. statist. Ass. 73: 724-729

Jordan, T E., Valiela, I. (1982). A nitrogen budget of the ribbed mussel, Geukensia demissa, and its significance in nitrogen flow in a New England salt marsh. Limnol. Oceanogr 27: 75-90

Kemp, P. F. (1988). Bacterivory by benthic ciliates: significance as a carbon source and impact on sediment bacteria. Mar. Ecol. Prog. Ser. 49: 163-169

Kreeger, D. A., Langdon, C. J., Newell, R. I. E. (1988). Utilization of refractory cellulosic carbon derived from Spartina alterniflora by the ribbed mussel Geukensia demissa. Mar Ecol. Prog. Ser. 42: 171-179

Kuenzler, E. J. (1961). Structure and energy flow in a mussel population in a Georgia salt marsh. Limnol. Oceanogr 6: 191-204

Lee, S., Fuhrman, J. A. (1987). Relationships between biovolumes and biomass of naturally derived marine bacterioplankton. Appl. envi.ron. Microbiol. 53: 1298-1303

Lucas, M. I., Newell, R. C., Shumway, S. E., Seiderer, L. J., Bally, R. (1987). Particle clearance and yield in relation to bacterioplankton and suspended particulate availability in estuarine and open coast populations of the mussel Mytilus edulis. Mar Ecol. Prog. Ser. 36: 215-224

McHenery, J. G., Birbeck, T. H. (1985). Uptake and processing of cultured microorganisms by bivalves. J. exp mar. Biol. Ecol. 90: 145-163

Møhlenberg, F., Riisgård, H. U. (1978). Efficiency of particle retention in 13 species of suspension feeding bivalves. Ophelia 17. 239-246

Moriarty, D. J. W. (1986). Measurement of microbial growth rates in aquatic systems using rates of nucleic acid synthesis. Adv. microb. Ecol. 9: 245-292

Moriarty, D. J. W., Pollard, P. C. (1981). DNA synthesis as a measure of bacterial productivity in seagrass sediments Mar. Ecol. Prog. Ser. 5: 151-156

Moriarty, D. J. W. Pollard, P. C. (1982). Diel variation of bacterial productivity in seagrass (Zostera capricorni) beds 
measured by rate of thymidine incorporation into DNA Mar. Biol. 72: 165-173

Moriarty, D. J. W., Pollard, P. C., Hunt, W. G., Moriarty, C. J., Wassenberg, T J. (1985). Productivity of bacteria and microalgae and the effect of grazing by holothurians in sediments on a coral reef flat. Mar Biol. 85: 293-300

Muir, D., G., Seiderer, L. J., Davis, C. L., Painting, S. J., Robb F. T. (1986). Filtration, lysis and absorption of bacteria by mussels Chloromytilus meridionalis collected under upwelling and downwelling conditions. S. Afr. J. mar Sci. 4: $169-179$

Newell, R. I. E., Langdon, C. J. (1986). Digestion and absorption of refractory carbon from the plant Spartina alterniflora by the oyster Crassostrea virginica. Mar. Ecol. Prog. Ser. 34: 105-115

Newell, S. Y., Fallon, R. D., Sherr, B. F., Sherr, E. B. (1988) Mesoscale temporal variation in bacterial standing crop percent active cells, productivity and output in a saltmarsh tidal river. Verh. int. Verein. Limnol. 23: 1839-1845

Officer, C. B., Smayda, T J., Mann, R. (1982). Benthic filter feeding: a natural eutrophication control. Mar. Ecol. Prog Ser. 9: 203-210

Peterson, C. H., Black, R. (1987). Resource depletion by active suspension feeders on tidal flats: influence of local density and tidal elevation. Limnol. Oceanogr. 32: 143-166

Riemann, B. (1984). Determining growth rates of natural assemblages of freshwater bacteria by means of ${ }^{3} \mathrm{H}$-thymidine incorporation into DNA: comments on methodology. Arch. Hydrobiol. Beih. Ergeb. Limnol. 19: 67-80

Riemann, B., Bjomsen, P. K., Newell, S. Y., Fallon, R. D. (1987). Calculation of cell production of coastal marine bacteria based on measured incorporation of $\left[{ }^{3} \mathrm{H}\right]$-thymidine. Limnol. Oceanogr. 32: 471-476

Riisgård, H. U. (1988). Efficiency of particle retention and filtration rate in 6 species of Northeast American bivalves. Mar Ecol. Prog. Ser. 45: 217-223

Rublee, P. A., Merkel, S. M., Faust, M. A. (1983). Nutrient flux in the Rhode River: tidal transport of microorganisms in brackish marshes. Estuar. cstl Shelf Sci. 17: 669-680

Seiderer, L. J., Davis, C. L., Robb, F. T., Newell, R. C. (1984). Utilisation of bacteria as a nitrogen resource by kelp-bed mussels, Chloromytilus meridionalis. Mar. Ecol. Prog. Ser. 15: 109-116

This article was presented by Professor C. H. Peterson, Morehead City, N. Carolina, USA
Sherr, B. F., Sherr, E. B. (1984). The role of heterotrophic protozoa in carbon and energy flow in aquatic ecosystems. In: Klug, M. J., Ready, C. A. (eds.) Current perspectives in microbial ecology. Am. Soc. Microb., Washington, D.C., p. $412-423$

Sherr, B. F., Sherr, E. B., Andrew, T. L., Fallon, R. D., Newell, S. Y. (1986). Trophic interactions between heterotrophic protozoa and bacterioplankton in estuarine water analysed with selective metabolic inhibitors. Mar Ecol. Prog. Ser. 32: $169-179$

Sherr, E. B., Sherr, B. F. (1987). High rates of consumption of bacteria by pelagic ciliates. Nature, Lond. 325: 1388-1393

Shumway, S. E., Cucci, T L., Newell, R. C., Yentsch, C. M. (1985). Particle selection, ingestion, and absorption in filter-feeding bivalves. J. exp. mar. Biol. Ecol. 91: 77-92

Simon, M. (1987). Biomass and production of small and large free-living and attached bacteria in Lake Constance. Limnol. Oceanogr. 32: 591-607

Smith, J. M., Hopkinson, C. S. (1983). Biodeposition by and paleoecology of the ribbed mussel Geukensia demissa in a salt marsh, Sapelo Island, Georgia. In: Research reports presented to the University of Georgia marine Institute by summer-research participants, 1980-1982. Georgia J. Sci. 41: 93-96

Sokal, R. R., Rohlf, F. J (1981). Biometry. W. H. Freeman and Co., New York

Strathmann, R. R. (1967). Estimating the organic carbon content of phytoplankton from cell volume or plasma volume. Limnol. Oceanogr. 12: 411-418

Stuart, V., Field, J. G., Newell, R. C. (1982). Evidence for absorption of kelp detritus by the ribbed mussel Aulacomya ater using a new ${ }^{51} \mathrm{Cr}$-labelled microsphere technique. Mar. Ecol. Prog. Ser. 9: 263-271

Turley, C., Lochte, K. (1986). Diel changes in the specific growth rate and mean cell volume of natural bacterial communities in two different water masses in the Irish Sea. Microb. Ecol. 12: 271-282

Wildish, D. J., Kristmanson, D. D. (1984). Importance to mussels of the benthic boundary layer. Can. J. Fish. Aquat. Sci. 41: $1618-1625$

Wright, R. T., Coffin, R. B., Ersing, C. P., Pearson, D. (1982). Field and laboratory measurements of bivalve filtration of natural marine bacterioplankton. Limnol. Oceanogr 27: 91-98

Manuscript first received: January 13, 1989

Revised version accepted: August 30,1989 